\title{
Aplikasi Metode Self Potential untuk Pemetaan Sebaran Lindi di Wilayah Tempat Pembuangan Akhir (TPA) Putri Cempo Surakarta
}

\author{
Andri Wasis Handoko, Darsono, dan Darmanto \\ Jurusan Fisika, Fakultas MIPA, Universitas Sebelas Maret, Surakarta \\ andriwasishandokoandri@gmail.com
}

Received 29-12-2015, Revised 27-01-2016, Accepted 04-02-2016, Published 20-04-2016

\begin{abstract}
The distribution of leachate and the pattern of fluid flow in Tempat Pembuangan Akhir (TPA) Putri Cempo were mapped by utilizing the Self Potential method. Data acquisition was done before and after the rain with a fixed base techniques with 10 meters interval distance with total number of observations were 78 points for data acquisition. SP Data were processed using Surfer 11 software to generate the isopotential contours. It is found that the leachate distribution anomaly is indicated only for after the rain observation. Interpretation was done by Rao and Ram Babu Theory. The result of vertical spreading of anomalous 1 was found at the depth of the upper end (h) 5.45 meters, the depth of the lower end $(\mathrm{H})$ 17.62 meters and the angle of anomaly $(\theta) 84^{\circ}$ while the anomalous 2 was found at the depth of the upper end (h) 5.45 meters, the depth of the lower end (H) 11.22 meters and the angle of anomaly $(\theta) 73.7^{0}$. At the time before the rain, the pattern of fluid flow leading to the eastern part of the research area, while after the rain, the fluid flow coming from two directions, from the west and from the east of the research area leading to the central part of the research area.
\end{abstract}

Keywords: Self Potential, leachate, fixed base, TPA Putri Cempo

\section{ABSTRAK}

Telah dilakukan pemetaan sebaran lindi dan pola aliran fluida di wilayah Tempat Pembuangan Akhir (TPA) Putri Cempo dengan metode Self Potential. Pengambilan data dilakukan sebelum dan setelah hujan dengan teknik basis tetap dengan interval 10 meter. Titik pengambilan data sebanyak 78 titik. Data SP diolah menggunakan software Surfer 11 sehingga dihasilkan kontur isopotensial. Hasil dari pemetaan setelah hujan menunjukan adanya sebaran anomali yang diindikasikan sebagai akumulasi air lindi. Interpretasi kuantitatif menggunakan teori Rao dan Ram Babu. Hasil penyebaran anomali 1 secara vertikal didapatkan kedalaman ujung atas (h) 5,45 meter, kedalaman ujung bawah $(\mathrm{H})$ 17,62 meter dan sudut kemiringan anomali $(\theta)$ 840. Pada anomali 2 didapatkan kedalaman ujung atas (h) 5,45 meter, kedalaman ujung bawah $(\mathrm{H})$ 11,22 meter dan sudut kemiringan anomali ( $\theta$ ) 73,70. Pada saat sebelum hujan, pola aliran fluida mengarah ke bagian timur lokasi penelitian, sedangkan setelah hujan, aliran fluida berasal dari dua arah, yaitu dari arah barat dan dari arah timur lokasi penelitian mengarah ke bagian tengah dari lokasi penelitian.

Kata kunci: Self Potential, lindi, basis tetap, TPA Putri Cempo

\section{PENDAHULUAN}

TPA Putri Cempo terletak di Jatirejo RT 06/11, Kelurahan Mojosongo, Kecamatan Jebres, Surakarta. TPA Putri Cempo merupakan salah satu tempat pembuangan sampah akhir yang terdapat di Kota Surakarta dengan luas lahan 17 Ha, mempunyai topografi yang bergelombang yang terdiri dari perbukitan dan berlembah dengan ketinggian diantara 75195 meter diatas permukaan laut. TPA Putri Cempo terdiri dari beberapa sub tempat yaitu lahan untuk pemusahan sampah, makam, Instalasi Pembuangan Limbah Tinja (IPLT), dan kantor pengelola TPA Putri Cempo ${ }^{[1]}$.

Sistem pengolahan lindi di TPA Putri cempo menggunakan sistem Open Dumping sehingga lindi hanya mengalir mengikuti kemiringan tanah. Pada saat musim hujan, debit lindi yang masuk ke instalasi pengolahan begitu besar, sehingga bak pengumpul tidak mampu menahan laju aliran lindi. Akibatnya lindi yang masuk kebak pertama akan meluap 
dan tumpah ke tanah. Sehingga perkolasi air hujan dan proses infiltrasi menyebabkan lindi meresap kedalam tanah ${ }^{[2]}$.

Air lindi dapat merembes melalui tanah dan menyebabkan pencemaran air tanah yang ada di lokasi TPA. Perembesan ini tergantung pada sifat fisik dari tanah dasar TPA seperti permeabilitas, porositas, dan tekanan piezometrik. Perembesan air lindi melalui tanah terjadi secara perlahan dan jika di baawah lokasi TPA terdapat aliran air, maka air lindi akan mencemari aliran tersebut dengan kandungan zat yang cukup berbahaya bagi lingkungan ${ }^{[3]}$.

Perkolasi dari lindi ke dalam air tanah sangat mempengaruhi kualitas air tanah. Material logam berat yang menjadi penyebab pencemaran air yang terkandung dalam lindi antara lain $\mathrm{Cd}, \mathrm{Cu}, \mathrm{Fe}, \mathrm{Ni}, \mathrm{Pb}, \mathrm{Fe}$, dan $\mathrm{Zn}^{[4]}$.

Metode SP bisa digunakan untuk menentukan pemetaan sebaran aliran lindi di wilayah TPA. Seperti penelitian yang telah dilakukan oleh Rosid ${ }^{[5]}$ yang meneliti estimasi aliran air lindi di TPA Bantar Gerbang Bekasi menggunakan metode SP, maka penelitian sebaran lindi di wilayah TPA Putri Cempo juga bisa dilakukan dengan metode Self Potential.

Metode SP merupakan metode yang sederhana dan murah, namun metode ini dapat bekerja dengan baik jika digunakan untuk kegiatan eksplorasi bawah permukaan yang dangkal dengan kedalaman yang kurang dari 100 meter, apabila digunakan untuk kedalaman yang lebih dari 100 meter, maka hasilnya sudah tidak akurat ${ }^{[6]}$.

Metode self potensial merupakan metode geofisika yang memanfaatkan potensial listrik alami yang terdapat di dalam lapisan tanah. Banyak faktor yang menyebabkan terjadinya potensial listrik alami tersebut diantaranya proses difusi, proses elektrokinetik, dan proses mineralisasi. Proses-proses tersebutlah yang membangkitkan potensial listrik elektrokinetik, potensial difusi, potensial nerst dan potensial mineralisasi.

\section{Potensial elektrokinetik}

Potensial elektrokinetik (streaming potential) bernilai kurang dari $10 \mathrm{mV}$ dibentuk dari adanya elektrolit yang mengalir melalui medium yang mempunyai pori-pori atau kapiler. Ketika larutan elektrolit yang berada dalam pori-pori batuan mengalir, maka timbul potensial elektrolit. Beda tekanan hidrostatik $\Delta P$ menimbulkan beda potensial listrik $\Delta V$. Hubungan ini dikenal dengan Persamaan Helmoltz-Smoluchowski pada Persamaan 1.

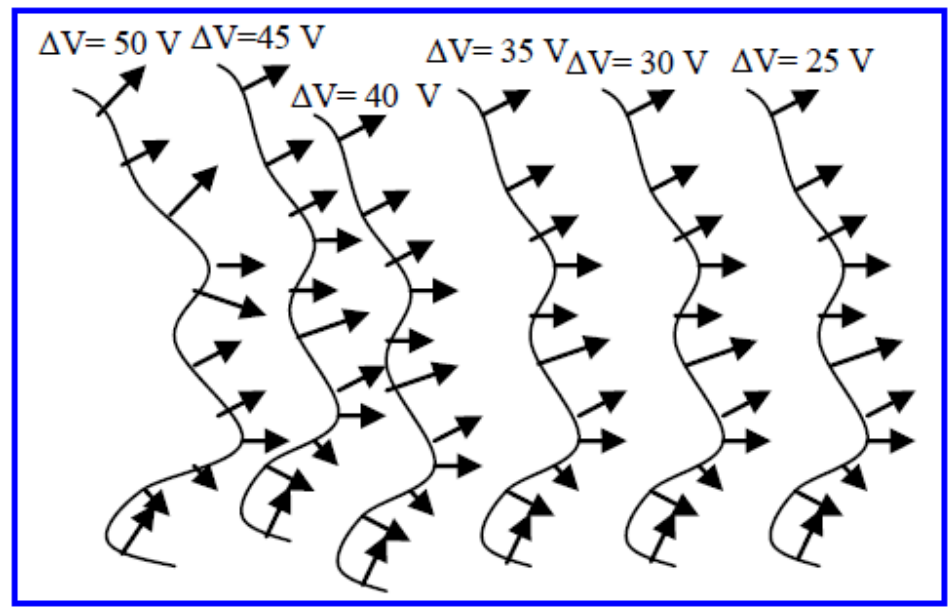

Gambar 1. (Coulor online) Arah arus listrik (tanda panah) akan selalu tegak lurus terhadap bidang ekipotensia. Arah aliran fluida searah dengan arah arus listrik ${ }^{[5]}$. 


$$
\delta \mathrm{V}=\frac{\varepsilon \mu C_{E} \delta P}{4 \pi \eta}
$$

dengan $\delta \mathrm{V}$ beda potensial listrik, $\varepsilon$ konsanta dielektrik, $\mu$ resistivitas elektrolit, $\mathrm{C}_{\mathrm{E}}$ koefisien kopling elektrofiltrasi, $\delta \mathrm{P}$ beda tekanan hidrostatik, dan $\eta$ viskositas dinamis elektrolit. Sesuai dengan formula diatas, maka aliran fluida akan searah dengan arah arus listri. Hal ini dapat ditunjukan dengan Gambar 1.

\section{Potensial Difusi}

Apabila konsentrasi elektrolit di dalam tanah bervariasi secara lokal maka variasi konsentrasi elektrolit di dalam tanah akan menyebabkan perbedaan mobilitas kation dan anion sehingga dapat menimbulkan potensial difusi. Formula dari potensial difusi adalah sebagai berikut.

$$
\delta V_{d}=\frac{R T\left(I_{a}-I_{c}\right) C_{E} \delta P}{F n\left(I_{a}-I_{c}\right)} \ln \frac{C_{1}}{C_{2}}
$$

Dengan R konstanta gas umum $\left(8,314 \mathrm{JK}^{-1} \mathrm{~mol}^{-1)}\right.$, $\mathrm{T}$ suhu mutlak $(\mathrm{K}), \mathrm{I}_{\mathrm{a}}$ mobilitas anion (+ve), $\mathrm{I}_{\mathrm{c}}$ mobilitas kation (-ve), $\mathrm{C}_{1}$ kosentrasi larutan 1 (mol), $\mathrm{C}_{2}$ kosentrasi larutan 2 (mol), dan F konstanta Faraday $\left(9,65 \times 10^{4} \mathrm{Cmol}^{-1}\right)$.

\section{Potensial Nerst}

Potensial nerst (shale) terbentuk diantara dua elektroda yang identik yang tercelup ke dalam elektrolit homogen yang mempunyai konsentrasi yang berbeda. Besarnya potensial listrik dirumuskan menjadi :

$$
\delta V_{S}=\frac{R T}{F n} \ln \frac{C_{1}}{C_{2}}
$$

Dengan R konstanta gas umum $\left(8,314 \mathrm{JK}^{-1} \mathrm{~mol}^{-1)}\right.$, T suhu mutlak $(\mathrm{K}), \mathrm{C}_{1}$ kosentrasi larutan 1 (mol), $\mathrm{C}_{2}$ kosentrasi larutan 2 (mol), dan F konstanta Faraday $\left(9,65 \times 10^{4} \mathrm{Cmol}^{-1}\right)^{[5]}$.

\section{Potensial Mineralisasi}

Apabila ada 2 macam logam yang dimasukan kedalam suatu larutan yang homogen, maka akan timbul beda potensial pada logam tersebut. Beda potensial inilah yang disebut potensial kontak elektrolit. Timbulnya potensial kontak elektrolit dan potensial elektrokimia pada daerah yang banyak mengandung mineral dapat diukur pada permukaan dimana mineral tersebut berada, sehingga kedua proses timbulnya potensial itu disebut dengan potensial mineralisasi. Nilai dari potensial mineralisasi kurang dari $100 \mathrm{mV}^{[7]}$.

\section{Penafsiran benda penyebab anomali model lempeng miring}

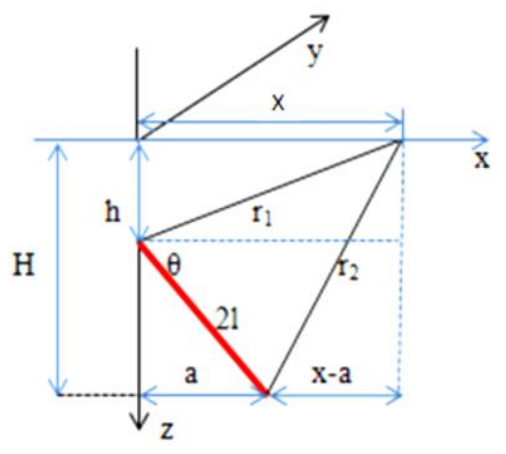

Gambar 2. Geometri model lempeng miring 
Model lempeng miring 2 dimensi yang ditunjukkan pada Gambar 2 sering digunakan untuk interpretasi data SP. Model lempeng miring untuk interpretasi anomali SP telah dikembangkan oleh Rao dan Babu.

Dalam sistem koordinat kartesian O berada di ujung batas lempeng, sumbu Y terletak pada arah strike, sedangkan sumbu $Z$ adalah arah vertikal. Dip $(\theta)$ dari lempeng diukur searah jarum jam terhadap sumbu $X$ positif. Untuk kasus ini besarnya potensial diri yang terukur di setiap titik P sepanjang profil yang sejajar sumbu X, dirumuskan dengan persamaan :

$$
V_{(x)}=M \ln \frac{r_{1}^{2}}{r_{2}^{2}}
$$

Bila $\mathrm{r}_{1}$ dan $\mathrm{r}_{2}$ pada Persamaan 1 dinyatakan dalam $\mathrm{x}$, maka didapat :

$$
V_{X}=\operatorname{Mln} \frac{x^{2}+h^{2}}{(x-a)^{2}+H^{2}}
$$

Dimana,

$$
M=\frac{I \rho}{2 \pi} \operatorname{dan} a=\frac{H-h}{\tan \theta}
$$

Dimana, $I$ merupakan rapat arus per satuan panjang. $\rho$ merupakan resistivitas medium, $x$ merupakan jarak titik origin $(0,0)$ ke titik P. $h$ merupakan kedalaman ujung atas lempeng. $H$ merupakan kedalaman ujung bawah lempeng. $\theta$ merupakan sudut kemiringan lempeng terhadap arah horizontal.

Apabila ditentukan, $x_{0}$ adalah jarak $\frac{1}{2} V_{\max }$ dan $V_{\min } . x_{s}$ adalah jarak simetris yaitu jarak dari titik origin ke titik yang mempunyai amplitudo yang sama tetapi berlainan tanda. $x_{\max }$ adalah jarak dari titik origin ke titik yang mempunyai voltase maksimum. $x_{\text {min }}$ adalah jarak dari titik origin ketitik yang mempunyai voltase paling minimum.

Parameter-parameter darin lempeng yang terdiri dari kedalaman ujung atas $(h),(H)$, dan kemiringan benda penyebab anomali $(\theta)$ dapatdihitung dari jarak-jarak $x_{0}, x_{s}, x_{\min }, x_{\max }$, yaitu dengan menggunakan persamaan-persamaan :

$$
\begin{aligned}
& h=\left(\left|x_{\text {max }} \cdot x_{\text {min }}\right|\right)^{\frac{1}{2}} \\
& a=\frac{x_{s}-h^{2}}{2 x_{0}} \\
& H=\left(x_{s}^{2}-a^{2}\right)^{\frac{1}{2}} \\
& \theta=\tan ^{-}\left(\frac{H-h}{a}\right)
\end{aligned}
$$

\section{METODE}

\section{Waktu dan Tempat Penelitian}

Penelitian ini dilaksanakan pada bulan September 2015 sampai dengan November 2015. Lokasi pengambilan data adalah di sekitar Tempat Pembuangan Akhir (TPA) Putri Cempo, tepatnya di Desa Plesungan Kecamatan Gondang Rejo Kabupaten Karanganyar, yang ditunjukkan pada Gambar 3. 


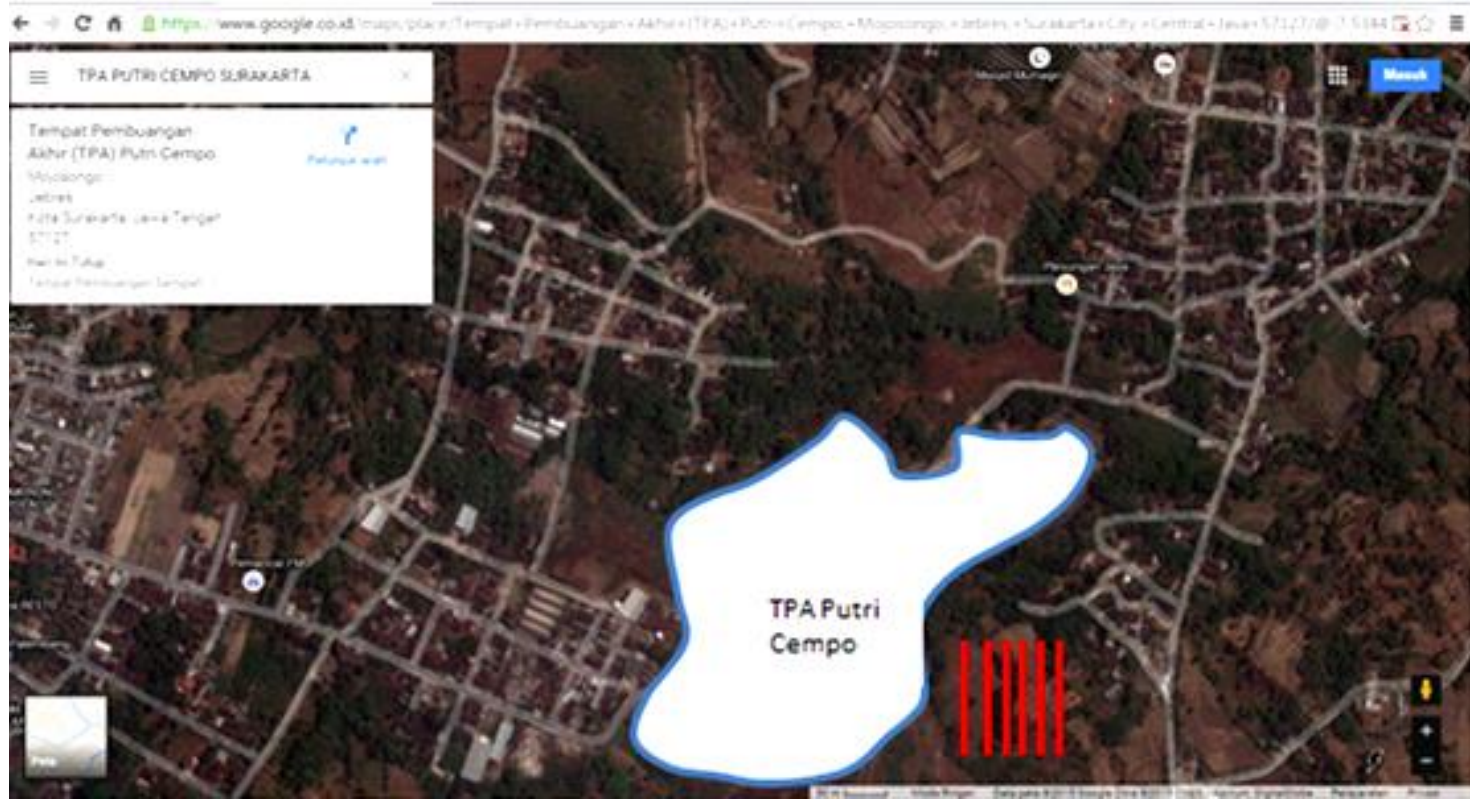

Gambar 3. (Colour online) Lokasi daerah penelitian dengan lintasan grid pengukuran data SP yang ditunjukan dengan garis merah.

\section{Peralatan}

Peralatan yang digunakan untuk pengambilan data di lapangan (ditunjukkan oleh Gambar

4) adalah sebagai berikut :

1. 4 Elektroda Pouros pot

2. 2 Kabel rol

3. 3 Handy Talky (HT)

4. 2 Multimeter Digital (Sanwa Cd800a)

5. Skop

6. Global Positioning System (GPS)

7. Larutan $\mathrm{CuSO}_{4}$
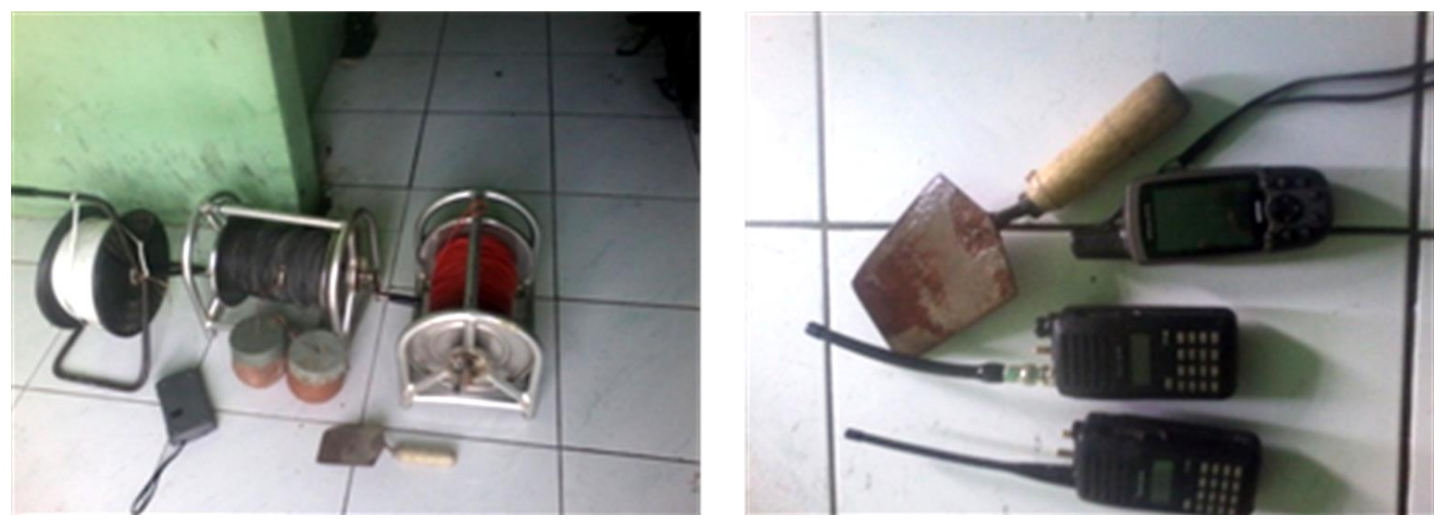

Gambar 4. (Colour online) Peralatan pengambilan data SP

\section{Pengambilan Data}

Pengambilan Data meliputi meliputi langkah-langkah berikut :

Survei PENDAHULUAN, merupakan suatu langkah untuk mengetahui keadaan atau kondisi tempat penelitian. Dalam survei ini bermaksud untuk mengetahui keadaan medan yang akan digunakan sebagai tempat penelitian, seperti derajat lintang dan bujur, kondisi lokasi pengambilan data. 


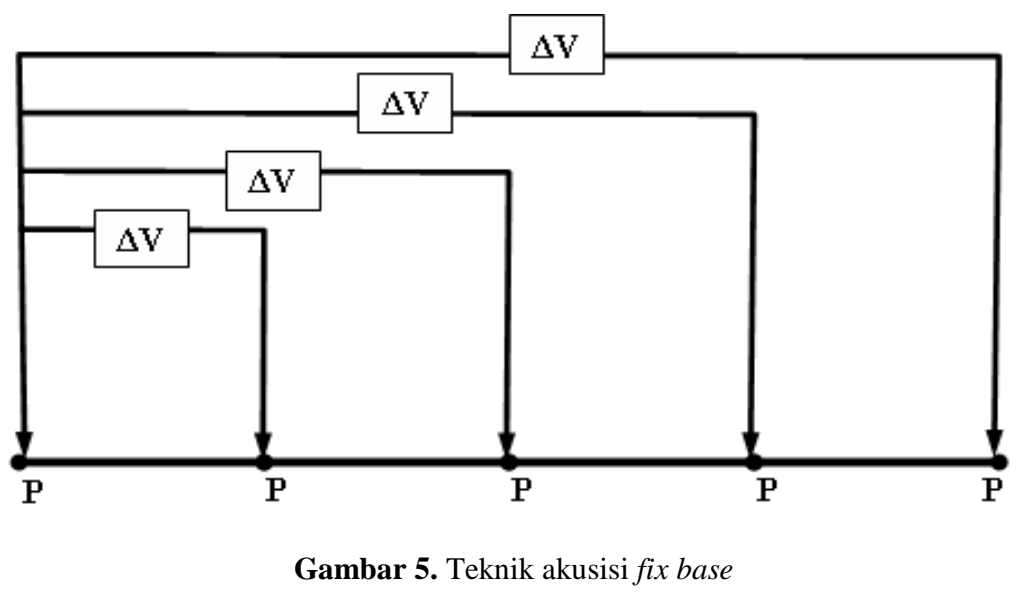

Kalibrasi alat, merupakan suatu langkah yang bertujuan untuk memperoleh data lapangan yang baik. Kalibrasi alat dilakukan dengan cara mengukur beda potensial diantara dua elektroda porous pot yang dipasang di air yang berjarak kurang lebih $10 \mathrm{~cm}$. Beda potensial yang diukur harus lebih kecil atau sama dengan 2 milivolt.

Pengambilan data meliputi nilai potensial di tiap titik pengukuran, nilai potensial untuk koreksi harian, dan sempel air sumur sebagai data pendukung. Pengambilan data tiap titik pengukuran menggunakan teknik basis tetap, yaitu dengan memposisikan satu elektroda tetap sebagai titik referensi, sedangkan elektroda yang lainnya berpindah dari satu titik ukur ke titik ukur lainnya. Pengambilan data potensial untuk koreksi harian dilakukan dengan mengukur nilai potensial di titik yang sama secara berulang dalam selang waktu tertentu. Sedangkan data sempel air sumur diambil dari sumur terdekat dengan lokasi penelitian dan dilakukan uji lab untuk mendukung hasil yang ingin dicapai. Pada penelitian ini dilakukan pengambilan data sebelum dan setelah hujan. Titik pengambilan data SP berjumlah 78 dengan spasi gridding 10 meter.

\section{Pengolahan}

Pengolahan data SP terkoreksi dilakukan dengan menggunakan Software Surfer 11. Hasil pengolahan data berupa kontur isopotensial untuk respon SP dan profil SP dengan jarak

\section{Interpretasi}

Interpretasi dilakukan secara kualitatif dan kuantitatif. Interpretasi kualitatif dilakukan untuk menganalisa hasil kontur isopotensial sedangkan interpretasi secara kuantitatif dilakukan untuk menentukan parameter-parameter dari anomali yang dihasilkan pada kontur isopotensial. Parameter-parameter yang dicari meliputi kedalaman ujung atas $(h)$ kedalaman ujung bawah $(H)$ dan sudut kemiringan dari anomali $(\theta)$. Penentuan parameterparameter anomali tersebut menggunakan model lempeng miring.

\section{HASIL DAN PEMBAHASAN}

\section{Hasil Uji Sempel Air}

Dari keseluruhan hasil uji baik pada lokasi 1 maupun lokasi 2, masing-masing menunjukan potensi pencemaran air oleh lindi yang ditunjukan dengan nilai kandungan Mn yang melebihi ambang batas baku mutu, sedangkan parameter-parameter yang lain nilainya cukup tingi dan hampir mendekati ambang batas dari baku mutu air minum berdasarkan SK Menkes No. 907/MENKES/SK/VII/2012. 
Tabel 1. Hasil uji sampel di Lboratorium Fisika Kimia BBTKLPP yogyakarta

\begin{tabular}{cccccc}
\hline \multirow{2}{*}{ No } & Parameter & Satuan & \multicolumn{2}{c}{ Hasil uji } \\
& & & Sampel & Sampel & Metode Uji \\
lokasi 1 & lokasi 2 & \\
\hline 1 & $\mathrm{Al}$ & $\mathrm{mg} / \mathrm{L}$ & 0,0632 & 0,0777 & APHA 2012, Section 3120-B \\
2 & $\mathrm{Fe}$ & $\mathrm{mg} / \mathrm{L}$ & $<0,0162$ & 0,0302 & SNI 6989.4-2009 \\
3 & $\mathrm{~Pb}$ & $\mathrm{mg} / \mathrm{L}$ & $<0.0161$ & $<0,0161$ & SNI 6989.8-2009 \\
4 & $\mathrm{Ni}$ & $\mathrm{mg} / \mathrm{L}$ & $<0,0130$ & $<0,0130$ & SNI 6989.18-2009 \\
5 & $\mathrm{Cu}$ & $\mathrm{mg} / \mathrm{L}$ & $<0,0069$ & $<0,0069$ & SNI 6989.6-2009 \\
6 & $\mathrm{Co}$ & $\mathrm{mg} / \mathrm{L}$ & $<0,0093$ & 0,0341 & SNI 6989.68-2009 \\
7 & $\mathrm{Ag}$ & $\mathrm{mg} / \mathrm{L}$ & $<0,0041$ & $<0,0041$ & SNI 6989.33-2009 \\
8 & $\mathrm{Mn}$ & $\mathrm{mg} / \mathrm{L}$ & $<0,0101$ & 1,0669 & SNI 6989.5-2009 \\
9 & $\mathrm{DHL}$ & $\mu \mathrm{mhos} / \mathrm{cm}$ & 578 & 1.448 & SNI06- 6989.1-2004 \\
10 & $\mathrm{Ph}$ & - & 6,9 & 6,9 & SNI06- 6989.11-2004 \\
11 & $\mathrm{Sulfat}$ & $\mathrm{mg} / \mathrm{L}$ & 8 & 194 & SNI 6989.20-2009 \\
12 & $\mathrm{Calsium}$ & $\mathrm{mg} / \mathrm{L}$ & 18,14 & 32,16 & SNI 06-6989.12-2004 \\
\hline
\end{tabular}

\section{Hasil Akuisisi}

Data hasil pengukuran Self Potensial berupa besaran potensial listrik dengan satuan $\mathrm{mV}$. Pada survei ini, pengambilan data SP dilakukan secara gridding. Jumlah data sebanyak 78 data dengan jarak spasi gridding 10 meter. Data hasil koreksi merupakan data SPR. Data secara umum mempunyai nilai SP yang kecil, berkisar antara $3 \mathrm{mV}$ sampai dengan -25 $\mathrm{mV}$. Hasil ini mendekati nilai potensial dari lindi dari penelitian Rosid (2011) bahwa konduktivitas lindi 2,68 mS $(1 \mathrm{mS}=1$ mili Siemens $=1 \mathrm{mV})$. Data SPR dibuat peta kontur isopotensial dengan menggunakan Software Surfer 11. Peta kontur isopotensial sebelum dan setelah hujan ditunjukan pada Gambar 6a dan Gambar 6b.

\section{Interpretasi kualitatif}

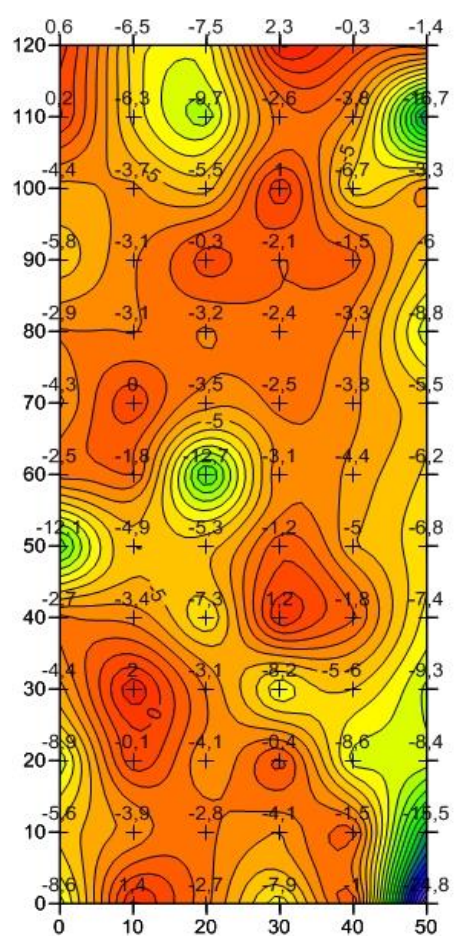

(a)

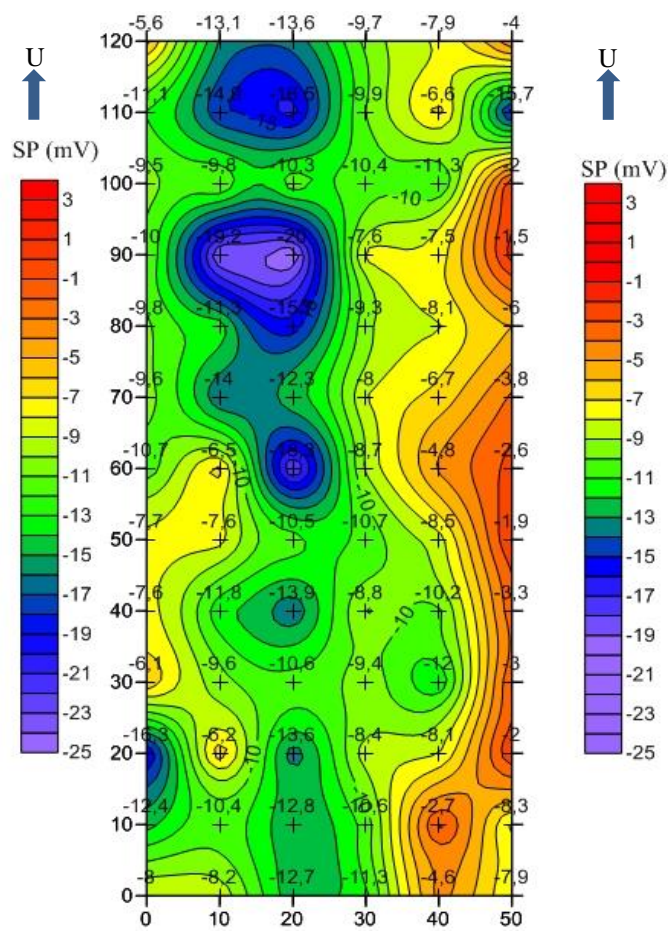

(b)

Gambar 6. (Colour online) Peta kontur isopotensial (a) sebelum hujan (b) setelah hujan 


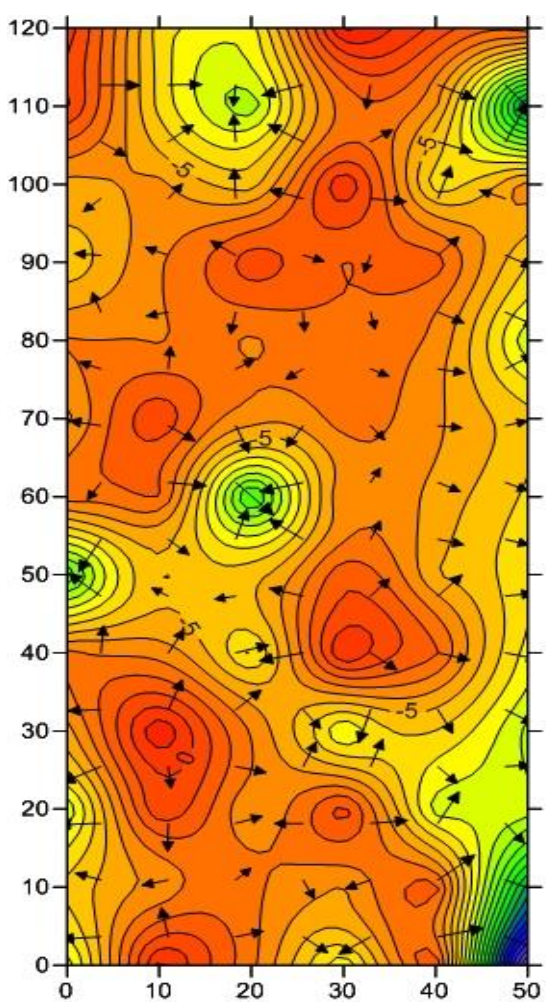

(a)
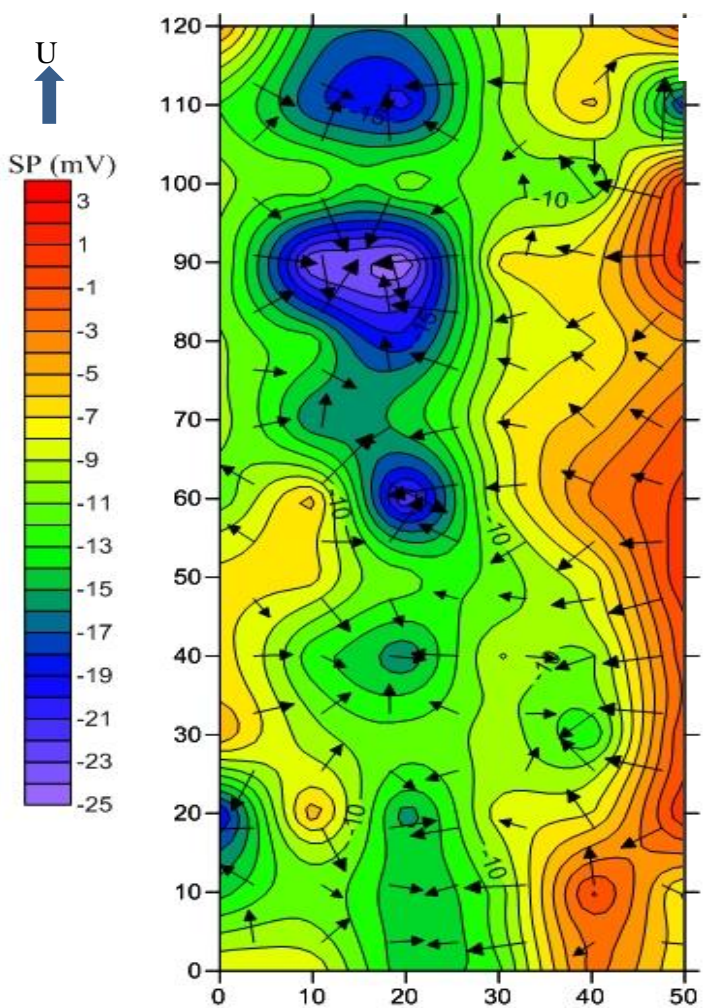

(b)

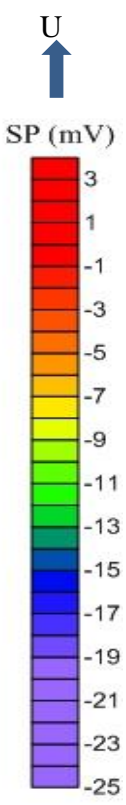

Gambar 7. (Colour online) Pola aliran fluida (a) sebelum hujan (b) setelah hujan

Dari hasil pengolahan data di setiap lokasi dengan menggunakan Software Surfer 11, pola sebaran anomali yang diindikasikan sebagai akumulasi lindi terlihat dari pola sebaran kontur isopotensial yang berwarna biru sampai ungu yang memiliki nilai SP lebih rendah dari daerah sekitar.

Jika Gambar 6a dibandingkan dengan Gambar 6b, terjadi pembentukan akumulasi anomali akibat adanya aliran fluida baik dari arah TPA maupun yang menuju arah TPA sehingga membentuk akumulasi anomali yang diindikasikan sebagai akumulasi air lindi.

Menurut Rosid (2011) arah arus listrik yang ditunjukan dengan tanda panah selalu tegak lurus terhadap bidang ekipotensial, sedangkan arah aliran fluida searah dengan arus listrik, sehingga dari hasil pemetaan dapat diinterpretasikan pola arah aliran fluida. Pada Gambar 7a, aliran fluida sebagian besar mengarah ke bagian timur lokasi penelitian. Aliran fluida membentuk suatu pola menerus dari arah TPA dan terakumulasi pada arah tenggara lokasi penelitian. Pada Gambar 7b, aliran fluida sebagian besar berasal dari dua arah, yaitu dari arah TPA dan dari arah timur lokasi penelitian dan terakumulasi menjadi 2 daerah akumulasi anomali SP.

\section{Interpretasi Kuantitatif}

Interpretasi secara kuantitatif dilakukan untuk mengetahui penyebaran lindi secara vertikal serta mengacu pada data geologi yang ada, serta anomali yang didapat dari peta kontur isopotensial, maka dilakukan pemodelan model lempeng miring. Parameter-parameter yang dicari berupa kedalaman ujung atas $(\mathrm{h})$, kedalaman ujung bawah $(\mathrm{H})$, dan sudut kemiringan dari anomali $(\theta)$. Penentuan parameter-parameter penyebab anomali tersebut tersebut menggunakan teori dari Rao dan Ram Babu. 


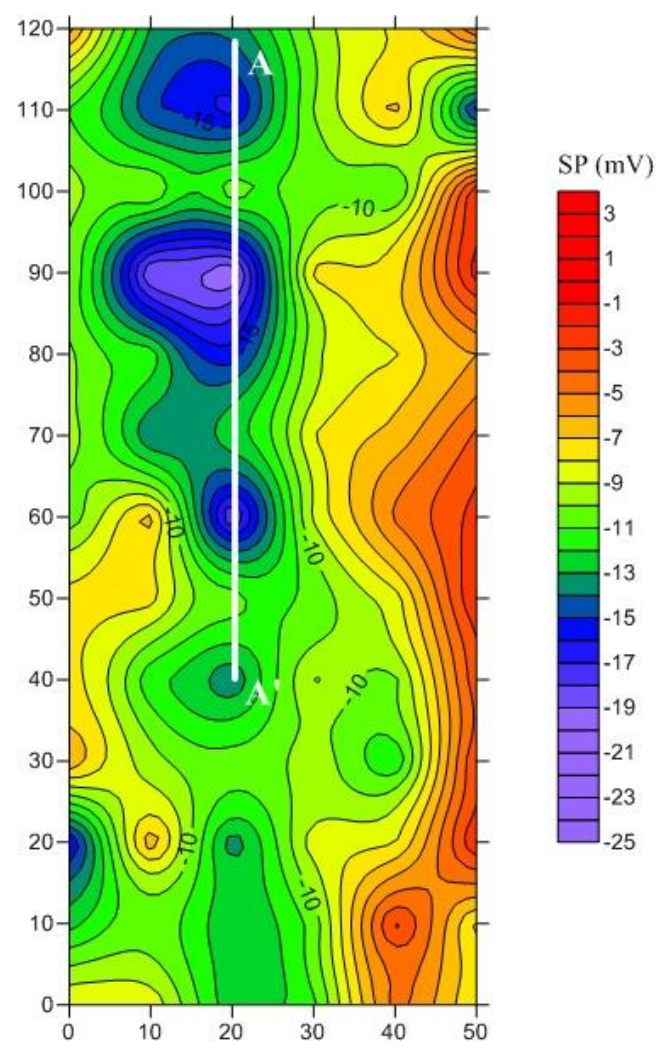

Gambar 8. (Colour online) Penampang A-A'

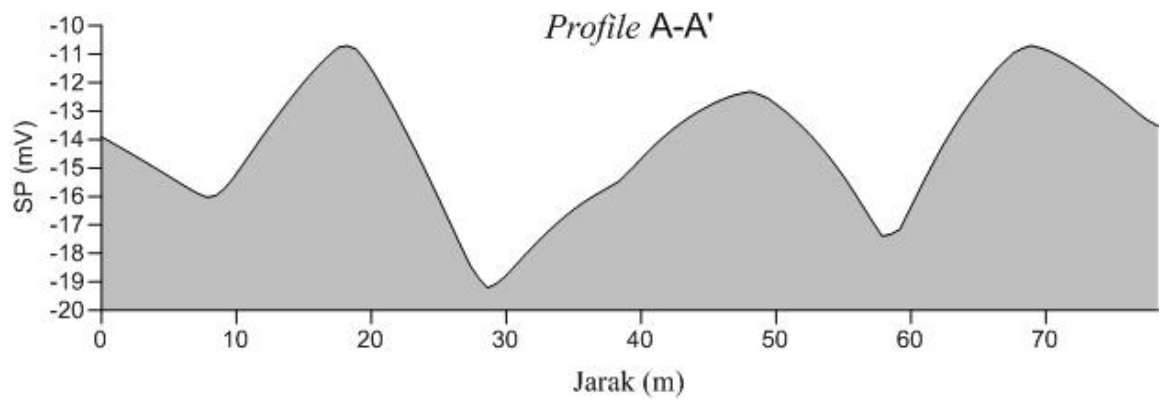

Gambar 9. (Colour online) Profil penampang A-A'

Dari kontur isopotensial, dibuat garis penampang diatas closure (tertutup) peta kontur yang diduga sebagai sumber anomali sehingga didapatkan kurva profil SP terhadap jarak. Garis penampang ditunjukan pada Gambar 8. Kurva profil yang dihasilkan dari penampang A-A' ditunjukan pada Gambar 9. Kurva profil A-A' digunakan untuk mencari parameterparameter anomali. Dari perhitungan berdasarkan persamaan 7, 8, 9, 10 didapatkan pada anomali 1 didapatkan kedalaman ujung atas (h) 5,45 meter, kedalaman ujung bawah $(\mathrm{H})$ 17,62 meter dan sudut kemiringan anomali $(\theta) 84^{\circ}$. pada anomali 2 didapatkan kedalaman ujung atas (h) 5,45 meter, kedalaman ujung bawah (H) 11,22 meter dan sudut kemiringan anomali $(\theta) 73,7^{0}$.

\section{KESIMPULAN}

Hasil dari pemetaan sebelum hujan tidak terdapat sebaran anomali sedangkan setelah hujan menunjukan adanya 2 sebaran anomali yang berjajar di bagian tengah lokasi penelitian diindikasikan sebagai akumulasi air lindi. Terjadinya sebaran anomali setelah hujan dikontrol oleh pergerakan aliran fluida bawah permukaan. Dari hasil perhitungan model lempeng miring, pada anomali 1 didapatkan h 5,45 meter, $\mathrm{H}$ 17,62 meter dan $\theta$ 840. Pada 
anomali 2 didapatkan h 5,45 meter H 11,22 meter dan $\theta$ 73,70. Pada saat sebelum hujan, pola aliran fluida mengarah ke bagian timur, sedangkan setelah hujan, aliran fluida berasal dari dua arah, yaitu dari arah barat dan dari arah timur lokasi penelitian mengarah ke bagian tengah dari lokasi penelitian.

\section{DAFTAR PUSTAKA}

1. Muhyidin, M. 2009. Analisis Keuangan Tempat Pembuangan Akhir (TPA) Putri Cempo Kota Surakarta. Skripsi. Universitas Muhammadiyah Surakarta.

2. Hardyanti, dan Huboyo, H. S. 2009. Evaluasi Instalasi Pengolahan Lindi Tempat Pembuangan Akhir Putri Cempo Kota Surakarta. Jurnal Presipitasi, Vol. 6, No. 1.

3. Saleh, C. 2012. Studi Perencanaan Instalasi Pengolahan Limbah Lindi Sebagai Kontrol Pemenuhan Baku Mutu Sesuai Kepmen 03/91. Media Teknik Sipil, Vol. 10, Hal. 87-94.

4. Nagarajan, R., Thirumalaisamy, S., Lakshumanan, E. 2012. Impact of Leachate on Groundwater Pollution due to Non-Engineered Municipal Solid Waste Landfill Sites of Erode City, Tamil Nadu, India. Iranian Journal of Environmental Health Science and Enginering, Vol. 6, No. 35.

5. Rosid, S. 2011. Estimasi Aliran Air Lindi TPA Bantar Gebang Bekasi menggunakan Metode SP. Jurnal Fisika, Vol. 1, No. 2.

6. Basid, A., Andrini, N., dan Arfiyaningsih, S. 2014. Pendugaan Reservoir Sistem Panas Bumi Dengan Menggunakan Survey Geolistrik, Resistivitas dan Self Potential. Jurnal Neutrino, Vol. 7, No. 1.

7. Indriana, R. D., Nurwidyanto, M. I., dan Haryono, K. W. 2007. Interpretasi Bawah Permukaan dengan Metode Self Potensial Daerah Bledug Kuwu Kradenan Grobogan. Berkala Fisika, Vol. 10, No. 3, Hal. 155-167.

8. Kartini, dan Danusaputro, H. 2005. Estimasi Penyebaran Polutan dengan Metode Self Potential. Berkala Fisika, Vol. 8, No. 1, Hal. 27-32. 